\title{
Disentangling supply and demand shifts: the impacts on world salmon prices
}

\author{
Eivind Hestvik Brækkan \\ School of Business and Economics, Faculty of Biosciences, Fisheries and Economics, UiT \\ The Arctic University of Norway, Breivika, N-9037, Tromsø, Norway \\ E-mail: eivind.h.brakkan@uit.no
}

\begin{abstract}
To understand price changes one must determine the relative impact of supply and demand shifts on price. Conditional on pre-determined supply and demand elasticities, we retrieve yearly shifts in regional supply and demand. The relative impact on price from each supply and demand shift is determined through an Equilibrium Displacement Model (EDM). This procedure is applied on a yearly basis for the world salmon market in the period from 2002 to 2011. The results indicate a large variation in demand and supply growth both over time and between regions. While average annual price impacts from supply or demand shifts from most regions were not statistically significant, price impacts from supply or demand shifts for specific periods are detected in all but one region. This indicates the use of smooth trend indicators is likely to be inappropriate for measuring supply and demand shifts and their impacts on price. The procedure presented in this paper can be a useful instrument for determining the relative impacts of supply and demand shifts on price in any market with unstable price behaviour.
\end{abstract}

Keywords: Market Analysis, Food Prices, Salmon Aquaculture, Equilibrium Displacement Model

JEL Classification Codes: Q11, Q13 


\section{Introduction}

'Stripped of the detail, commodity prices do indeed reflect shifts in supply relative to demand' (Tomek, 2000, p. 130)

Why do prices change? Dramatic price increases for a number of food commodities in recent years indicate large shifts in supply relative to demand. For any commodity, there can be multiple simultaneous shifts in supply and demand in different geographical locations. For a globally traded commodity, each of these shifts can affect the price, albeit to different extents. Determining the relative impacts of such supply and demand shifts on price is important for understanding commodity price behaviour. The objective of this article is twofold: Firstly, to determine regional and global supply and demand shifts using an approach that allows shifts to vary independently between years. Secondly, and mainly, to measure the relative impacts of each supply and demand shift on price. The procedure is applied on an annual basis to the global salmon market using trade data.

An approach by Marsh (2003) for computing changes in beef demand is used to compute yearly import demand and export supply shifts from all major exporting and importing regions of farmed salmon worldwide. While this procedure has been used to compute demand growth in the EU and France (Asche et al. 2011), and to compute the size and impact of a oneoff supply shift in Chile in the early 2000s (Kinnucan and Myrland 2006), this article extends the approach to all market participants in the global salmon market. The specification of demand and supply shifts was adjusted from the previous literature so that they could be applied in an EDM (see e.g. Piggott, 1992). This permits the determination of the relative price and quantity impact from each region's demand or supply shift. This approach requires price and quantity data, as well as appropriate elasticity parameters. Although being restrictive in its interpretative ability, this parsimonious approach allows a comparatively thorough analysis based on limited data.

\section{Background}

Over the past 50 years, most food commodity prices have steadily trended down, suggesting that productivity growth has outpaced demand growth (Alston et al., 2009). In recent years, however, many food commodity prices have increased dramatically. The (nominal) food price index of the Food and Agriculture Organization (FAO) of the United Nations hit an alltime high in early 2011. Since then prices have remained high and the food price index is currently 2.33 times higher than its base level value in 2000. Fig. 1 shows FAO's (nominal) 
food price indices for meat, dairy, cereals, oils, sugar and fish, in addition to the salmon price index constructed by Tveterås et al. (2012). Since the early 2000s, all these price categories began to increase to varying extents.

Fig. 1. FAO food price indices 1990-2013



Note: Price indices for meat, dairy, cereals, oils and sugar were retrieved from the FAO homepage www.fao.org. The price indices for fish and salmon were provided by Sigbjørn Tveterås.

If prices increase due to increased demand this has an entirely different implication than if they rise because of reduced supply. Demand growth will lead to increased production, to the extent that producers are able to respond to higher prices. If prices increase due to supply contractions, it could be a reflection of unsolved problems in the production process, a substitution of production away from food to other commodities, or a decline in productivity growth. Different causes of price changes have vastly different implications for food security and welfare both for producers and consumers. The task of identifying the factors behind price changes in food commodity markets is complex. Many of these factors are difficult, if not impossible, to measure appropriately. Thus, the simple question of "why do prices change?" usually requires elaborate investigation.

Trostle (2008) identifies several demand and supply factors that simultaneously contributed to a recent increase in food prices. Gilbert (2010) emphasizes the impact of common factors on the general level of agricultural food prices. He argues that investments in index- 
based agricultural futures markets were a major cause of the broad rise in food prices in 20072008. The fundamental driver of such index investments is the belief that rapid economic growth in China will increase demand for commodities in general. The Westernization of diets in Asian economies (Pingali 2007), along with rapid income growth, are also highlighted as important drivers (Enders and Holt 2012). Another driver is the diversion of food crops into the production of biofuels, which is generally considered to influence long-run agricultural price levels (Serra and Zilberman 2013). The recent price booms have also lead to increased interest in the Prebisch-Singer hypothesis of continuous long-term declines in primary commodity prices (Balagtas and Holt 2009; Harvey and Kellard 2010; Enders and Holt 2012). Results yield mixed evidence of the hypothesis' efficacy: Harvey and Kellard (2010) for instance, find longrun decline in the price of only 11 of 25 major commodities.

Shifting the focus back to recent developments, price increases since the early 2000 s varied considerably among various food commodities. Tveterås et al. (2012) notes that fish prices are less volatile than terrestrial food groups and do not appear to track any of the terrestrial food groups. Commodity-specific effects obviously play a major role in explaining the different price developments. While considerable efforts have been made to investigate the general food commodity price spikes, this article focuses on price impacts from demand and supply shifts of a specific food product; farmed salmon.

Seafood is one of the most traded food commodities worldwide. In 2010 fish accounted for $16.7 \%$ of the global population's intake of animal protein (FAO 2014). Aggregate fisheries production has remained relatively stable since the late 1980s (Asche and Bjørndal 2011), while aquaculture is one of the world's fastest-growing food production technologies (FAO 2014). Aquaculture is generally viewed as a highly promising food production technology that has the potential to be less environmentally challenging than other animal-based terrestrial food production (Asche 2008). Farmed salmon specifically is considered among the most sustainable animal-based food products in the world (Torrissen et al. 2011). Hence, aquaculture in general and farmed salmon in particular can play a vital part in sustainably supplying food to an increasing world population.

The global farmed salmon market is characterized by a highly traded, relatively homogenous product and an enormous growth in quantities over the last 30 years. Productivity growth caused prices to decline rapidly in the 1980s and 1990s (Andersen et al. 2008). In recent years, even at increasing quantities, both the price and volatility of salmon prices have increased (Øglend 2013). Increasing prices at higher quantities suggest demand is outstripping supply. Market expansion in product forms and geographical space are considered to be the main factors 
driving demand growth (Asche and Bjørndal 2011). Øglend (2013) argues that increasing price volatility of input factors and substitute products largely account for the increasing volatility of salmon prices, thus implying that both demand and supply shifts affect the price development of salmon. Price volatility in the salmon market can also be attributed to inelastic short-term supply and slow adjustments in production (ibid.). While inelastic supply can contribute to high price volatility, it does not imply any change in price per se. Any price change must essentially be due to either supply or demand shifts, or a combination of the two.

There are essentially two causal factors for supply shifts: increased use of inputs or productivity growth. The main input is the production site; a tightly regulated input in all major salmon-producing countries. Without relaxed government regulations, any growth in supply must come from productivity growth. Productivity growth, or technical change, can be analyzed using techniques such as stochastic frontiers or indices (Kumbhakar and Lovell 2000; Coelli et al. 2005). Asche et al. (2013) and Vassdal and Holst (2011) find productivity growth has slowed down since the early 2000s, suggesting the salmon farming industry has developed into a mature industry with lower growth rates. Still, in the long run technical progress does lead to supply growth (Asheim et al. 2011). If productivity is indeed slowing down, any significant supply expansion in the future is contingent upon a relaxation of government regulations.

The empirical literature on demand growth has relied mainly on using smooth operators such as a time trend (Deaton and Muellbauer 1980), or the use of relatively smooth indicators such as spending on advertisements or media coverage when investigating demand shifts over time (e.g. Kinnucan et al., 1997). This approach is commonly applied in empirical work on salmon demand (Bjørndal et al. 1992; Asche 1996; Xie et al. 2009; Xie and Myrland 2011). In this article, I adopt a parsimonious approach to measuring demand shifts; yearly changes in price and quantities are decomposed between regional supply and demand shifts, and the relative impact from each supply and demand shift on price is determined.

\section{Analytical Framework}

\section{Supply and demand Shifts}

Marsh (2003) uses an index approach for measuring yearly changes in the demand for beef. He defines shifts in the U.S. retail demand curve for beef as 'percentage differences between observed retail beef prices and estimated retail beef prices holding demand constant' (ibid. p. 903). 
A shift in demand between two periods is the horizontal movement of the demand schedule induced by changes in all exogenous variables affecting demand. Given an observed price change and a predetermined elasticity value, an expected quantity change can be determined. The expected change in quantity is compared to the actual quantity change. Any unexplained quantity change is a shift in demand between two periods. The formula for horizontal shifts in supply and demand between two periods is specified as follows (see Appendix for derivation and details):

$$
\begin{aligned}
& \gamma=Q^{*}-\varepsilon P^{*} \\
& \alpha=Q^{*}-\eta P^{*}
\end{aligned}
$$

Where $\gamma$ and $\alpha$ are the relative shifts in supply and demand and $Q^{*}$ and $P^{*}$ are the relative shifts in price and quantity between two periods. $\varepsilon$ and $\eta$ are predetermined price elasticities of supply and demand. Asterisks denote percentage change throughout the article. The specification of a demand shift is the horizontal equivalent of Muth's (1964) description of a vertical demand shift, which appears in his seminal paper that introduced the EDM, and is a common specification of a demand shift in EDMs. It can also be traced back to Leontief's definition of "Niveauverschiebungen" (Shifts of level) in his (unsuccessful) theory for deriving supply and demand curves from price and quantity data only (Leontief 1929). Ordinarily an EDM solves for the equilibrium quantities and prices for one or more shifts in some exogenous variables affecting demand or supply, while suppressing all other variables. Here the shifts in demand and supply are retrieved from the observed changes in prices and quantities and the predetermined elasticity values. The underlying exogenous variables behind the shifts are not identified.

A shift in demand can be interpreted as the percentage change in quantity demanded, when price is held constant. A positive demand shift between two periods indicates an outward movement of the demand schedule. This indicates consumers want to consume a higher quantity of salmon at a given price. For example, a $10 \%$ positive shift in demand implies the importing region will bring in $10 \%$ more salmon than in the previous period if the price remains unchanged. Kinnucan and Myrland (2006) extends Marsh's (2003) procedure to measure supply shifts. The interpretation of a supply shift is analogous to the demand shift: a supply shift is the percentage change in quantity supplied that is not due to a change in price. A positive supply shift indicates exporters are willing to sell more salmon at a given price. 
The shifts in demand and supply are retrieved yearly for each major importing and exporting region of salmon worldwide, and their impacts are assessed in an EDM of the world salmon market.

Data

Yearly trade and production data for all major salmon exporting and importing regions from 2002-2011 was supplied by the Norwegian Seafood Council. The price variable is the trade weighted export price in 2011 euros, deflated by Eurostat's Harmonized Index of Consumer Prices $(\mathrm{HICP})^{2}$. The quantity variables are net exports and imports, i.e. exports minus imports, and vice versa. The use of trade data is primarily the result of data availability and in line with most literature on the world salmon market. An implication of using trade data is that the retrieved import demand and export supply shifts are influenced by shifts in domestic demand and supply. To minimize such impacts the EU is separated into two regions: one importing region (The EU mainland) and one exporting region (UK/Ireland). See Table 1 for background data.

The model is based on the simplifying assumption that the world salmon market is sufficiently competitive so that the Law of One Price (LOP) holds. Empirical support for this assumption is provided by Asche et al. (1999, 2005). Existing literature has found that farmed Atlantic salmon determines the prices for both farmed and wild salmon (Asche et al., 1999), and farmed salmon represents the major share of world supply and trade (Knapp et al., 2007). Attention is hence restricted to farmed Atlantic salmon.

Table 1. Background data 2002-2011 - import and export quantities and price

\begin{tabular}{llcl} 
& & Annual & Annual average \\
Variable & Definition & $\begin{array}{l}\text { average } \\
\text { 2002-2006 }\end{array}$ & \\
& & $5087-2011$ & 827 \\
\hline$X_{N}$ & Norway's net exports & 298 & 244 \\
$X_{C H}$ & Chile's net exports & 65 & 67 \\
$X_{C A}$ & Canada's net exports & 49 & 30 \\
$X_{U K / I R}$ & UK/Ireland's net exports & 30 & 40 \\
$X_{F A}$ & The Faroe Islands' net exports & &
\end{tabular}

\footnotetext{
${ }^{2}$ Note that by deflating the price and expressing it in euros, the price of salmon is actually slightly lower in 2011 compared to 2002, as opposed to what can be observed in figure 1 where the salmon price index is denominated in nominal US dollars
} 


$\begin{array}{llll}X_{R O W} & \text { ROW's net exports (producing countries) } & 3 & 3 \\ \sum X_{i} & \text { Total net exports } & 954 & 1211 \\ M_{E U^{\text {main }}} & \text { The EU mainland's net imports (EU less } & 473 & 607 \\ & \text { UK/Ireland) } & & \\ M_{U S} & \text { US' net imports } & 273 & 252 \\ M_{R U} & \text { Russia's net imports } & 41 & 88 \\ M_{J A} & \text { Japan's net imports } & 57 & 41 \\ M_{B R} & \text { Brazil's net imports } & 17 & 40 \\ M_{R O W} & \text { ROW's net imports (consuming countries) } & 93 & 185 \\ \sum M_{j} & \text { Total net imports } & 954 & 1211 \\ P & & & 3.88\end{array}$

Note: Totals might not sum up due to rounding. Price is the quantity-weighted export price in real 2011 euros. Source: Norwegian Seafood Council.

\section{Model}

The market for salmon is specified as follows, based on Kinnucan and Myrland's (2005, 2006) model of the world market for salmon:

$$
\begin{aligned}
& X_{i}=X_{i}\left(P, \mathrm{Z}_{i}\right) \quad i=N O, C H, C A, U K / I R, F A, R O W \\
& M_{j}=M_{j}\left(P, \mathrm{~A}_{j}\right) \quad j=E U^{\text {main }}, U S, J A, R U, B R, R O \\
& \sum_{i}^{n} X_{i}=\sum_{j}^{m} M_{j}=Q_{t o t}
\end{aligned}
$$

$X_{i}$ represents the quantity exported by region $i$, and $\mathrm{Z}_{\mathrm{i}}$ is a vector of all exogenous variables affecting the export supply of salmon from region $i . M_{j}$ represents the quantity imported by region $j$, and $\mathrm{A}_{\mathrm{j}}$ is a vector of all exogenous variables that affect import demand for region $j$. The equilibrium condition (4) states that total quantity exported must be equal to total quantity imported. Equations (3) and (4) can be expressed in percentage change form as follows:

$$
\begin{aligned}
& X_{i}^{*}=\varepsilon_{i} P^{*}+\gamma_{i} \\
& M_{j}^{*}=\eta_{j} P^{*}+\alpha_{j} \\
& \sum_{i}^{n} k_{x i} X_{i}^{*}=\sum_{j}^{m} k_{m j} M_{j}^{*}
\end{aligned}
$$


where $\varepsilon_{i}$ and $\eta_{j}$ are export supply and import demand elasticities for region $i$ and $j . \gamma_{i}=$ $\frac{\mathrm{Z}_{i} \partial X_{i}}{X_{i} \partial \mathrm{Z}_{i}} \frac{d \mathrm{Z}_{i}}{\mathrm{Z}_{i}}=\varepsilon_{Z_{i}} Z_{i}^{*}$ and $\alpha_{j}=\frac{A_{j} \partial M_{j}}{M_{j} \partial \mathrm{A}_{j}} \frac{d A_{j}}{A_{j}}=\eta_{M_{j}} A_{j}^{*}$ are horizontal shifts in supply and demand computed as described in equations (1) and (2) in the previous section. $\gamma_{i}$ can be interpreted as the relative shift in supply caused by changes in $Z_{i}$, holding price constant, and $\varepsilon_{Z_{i}}$ is a vector of elasticity scalars corresponding with $Z_{i} . \alpha_{j}$ is the corresponding shift in demand caused by changes in $A_{j}$, and $\eta_{M_{j}}$ a vector of corresponding elasticity scalars. $k_{x i}=\frac{X_{i}}{\sum_{i}^{6} X_{i}}$ and $k_{m j}=\frac{M_{j}}{\sum_{j}^{6} M_{j}}$ is each region's export or import quantity share of total world exports or imports (See Table 2 for baseline data). The model thus consists of 13 endogenous variables: one to represent the market clearing price; six to represent region-specific changes in export quantities; and six to represent region-specific changes in import quantities. Equilibrium is displaced by changes in 12 exogenous variables: six to represent changes in import demand $\alpha_{j}$ from each importing region; and six to represent changes in export supply $\gamma_{i}$ from each exporting region.

\section{Parameterization}

\section{Table 2. Parameter definitions and values}

\begin{tabular}{lll} 
Parameter & Definition & Values \\
\hline$x_{N O}$ & Share of Norway's production exported & 0.96 \\
$x_{C H}$ & Share of Chile's production exported & 0.92 \\
$x_{C A}$ & Share of Canada's production exported & 0.60 \\
$x_{U K / I R}$ & Share of UK/Ireland's production exported & 0.25 \\
$x_{F A}$ & Share of the Faroe Islands' production exported & 1 \\
$x_{R O W}$ & Share of ROW's production exported & 0.12 \\
$m_{E U}$ main & Share of the EU mainland's consumption imported & 1 \\
$m_{U S}$ & Share of US' consumption imported & 0.95 \\
$m_{R U}$ & Share of Russia's consumption imported & 1 \\
$m_{J A}$ & Share of Japan's consumption imported & 1 \\
$m_{B R}$ & Share of Brazil's consumption imported & 1 \\
$m_{R O W}$ & Share of ROW's consumption imported & 1 \\
$\varepsilon_{N O}$ & Norway's export supply elasticity & 0.14 \\
$\varepsilon_{C H}$ & Chile's export supply elasticity & 0.20
\end{tabular}




\begin{tabular}{|c|c|c|}
\hline$\varepsilon_{C A}$ & Canada's export supply elasticity & 0.83 \\
\hline$\varepsilon_{U K / I R}$ & UK/Ireland's export supply elasticity & 2.2 \\
\hline$\varepsilon_{F A}$ & The Faroe Islands' export supply elasticity & 0.10 \\
\hline$\varepsilon_{R O W}$ & ROW's export supply elasticity & 8 \\
\hline$\eta_{E U^{\text {main }}}$ & The EU Mainland's import demand elasticity & -1.1 \\
\hline$\eta_{U S}$ & US‘ import demand elasticity & -0.75 \\
\hline$\eta_{R U}$ & Russia's import demand elasticity & -1 \\
\hline$\eta_{J A}$ & Japan's import demand elasticity & -1.5 \\
\hline$\eta_{B R}$ & Brazil's import demand elasticity & -1 \\
\hline$\eta_{R O W}$ & ROW's import demand elasticity & -1 \\
\hline$k_{x N}$ & Norway's share of world exports & 0.61 \\
\hline$k_{x C H}$ & Chile's share of world exports & 0.26 \\
\hline$k_{x C A}$ & Canada's share of world exports & 0.06 \\
\hline$k_{x U K / I R}$ & UK/Ireland's share of world exports & 0.04 \\
\hline$k_{x F A}$ & Faroe Islands' share of world exports & 0.03 \\
\hline$k_{x R O W}$ & ROW's share of world exports & 0.003 \\
\hline$k_{m E U^{\text {main }}}$ & THE EU mainland's share of world imports & 0.50 \\
\hline$k_{m U S}$ & US' share of world imports & 0.25 \\
\hline$k_{m R U}$ & Russia's share of world imports & 0.06 \\
\hline$k_{m J A}$ & Japan's share of world imports & 0.05 \\
\hline$k_{m B R}$ & Brazil's share of world imports & 0.03 \\
\hline$k_{m R O W}$ & ROW's share of world imports & 0.12 \\
\hline
\end{tabular}

Notes: Values for share of world exports and imports are averages between 2002 and 2011.

Parameter definitions and values are reported in Table 2. Numerical values for the model's structural elasticities $\varepsilon_{i}$ and $\eta_{j}$ are derived using the following formulas for export supply and import demand:

$$
\begin{aligned}
\varepsilon_{i} & =\left(e_{S_{i}}+\left(1-x_{i}\right) e_{D_{i}}\right) / x_{i} \\
\eta_{j} & =-\left(\left(1-m_{j}\right) e_{S_{j}}+e_{D_{j}}\right) / m_{j}
\end{aligned}
$$

Where $x_{i}$ is the share of production exported from the producing region and $m_{j}$ is the share of consumption imported for the importing region. $e_{S_{i, j}}$ and $e_{D_{i, j}}$ are (absolute) domestic supply 
and demand elasticities within each specific region. For a thorough derivation of the formula see e.g. Houck (1986, pp. 33-34).

Existing literature report values for the elasticity of supply in the range of one year or shorter between 0.05 and 0.15 (Andersen et al. 2008; Asheim et al. 2011). There is no indication in the literature that the elasticity of supply of salmon varies with location. Since the focus in this article is on yearly changes, the domestic elasticity of supply $e_{S_{i, j}}$ is assumed uniform at 0.1 for all salmon-producing regions. Any long-term supply response to prices in previous periods is captured by the retrieved yearly shifts in supply.

While several studies on salmon demand report elasticity values larger in (absolute) magnitude than 1 (Asche et al., 1999, 1998, 1997; DeVoretz and Salvanes, 1993), it has been suggested that the demand elasticity for farmed salmon has declined over time as a result of increasing supply (Asche 1996), and may already be inelastic (Asche and Bjørndal 2011). A review of recent literature using data from between the late 1990s and 2010 shows a wide range of reported demand elasticity values ${ }^{3}$. In regions where estimates from previous studies are available, a mean of estimated elasticity values is used. The mean is weighted by consumption shares where such information is available. The following values for the domestic demand elasticity $e_{D_{i}}$ are used: for USA 0.7 The EU mainland 1.1 (Xie and Myrland 2011), UK/Ireland 0.6 (Fousekis and Revell 2004), Japan 1.5 (Sakai et al. 2009). In regions where no estimates based on recent data are available, $e_{D}$ is set to 1 , based on Xie et al.'s (2009) estimate of the aggregate export demand elasticity for fresh farmed salmon.

\section{Price impacts}

For any set of elasticity values, equations (3') to (5') can be used to determine the annual relative changes in equilibrium quantities and prices for given changes in the exogenous variables. The methodology is applied consecutively for each year from 2003 to 2011. The effects of each exogenous variable on equilibrium price and trade flows are computed by first expressing the model in matrix form as follows:

$$
A y=B x
$$

\footnotetext{
${ }^{3}$ Demand elasticities vary between -0.2 and -1.7 , with mean and median around -0.75 (Fousekis and Revell 2004; Davis et al. 2007; Hong and Duc 2009; Sakai et al. 2009; Xie et al. 2009; Tiffin and Arnoult 2010; Asheim et al. 2011; Muhammad and Jones 2011; Xie and Myrland 2011; Chidmi et al. 2012; Singh et al. 2012; Jones et al. 2013). The values vary by product form, period length, income level and market location.
} 
where $A$ is a $13 \times 13$ matrix of elasticities associated with the model's endogenous variables, $y$ is an $13 \times 1$ vector containing the endogenous variables, $B$ is a $13 \times 12$ matrix of parameters corresponding to the exogenous variables, and $x$ is a $12 \times 1$ vector of the exogenous variables. The relative changes in the endogenous variables $y$ caused by the relative changes in the exogenous variables $x$ are computed by solving the matrix set (8) as follows:

$$
y=E x
$$

$E=A^{-1} B$ is a matrix of reduced-form elasticities that take into account the general equilibrium effects of exogenous shifts in export supply and import demand as reflected in the $\gamma_{\mathrm{i}}$ and $\alpha_{\mathrm{j}}$ parameters. (9) describes the impacts of each shift in supply and demand on equilibrium price and quantities. For a supply shift, the impact on price and quantities depends on the size of the supply shift $\gamma_{i}$, the relative share of total world exports for the exporting region and a weighted share of all regions' elasticities of export supply and import demand. Similarly, the impact of a demand shift depends on the size of the demand shift $\alpha_{j}$, the relative share of total world imports for the importing region, and the weighted shares of the elasticities of export supply and import demand. Thus, the matrix specifies the impact of every shift in demand and supply on price and quantity formation in all exporting and importing markets. Any shift in price and quantities are decomposed between the shifts in supply and demand from exporting and importing regions. The model structure implies that predicted change in price and quantity are equal to observed price and quantity changes.

Some observations of the impacts of specific supply and demand shifts are in order. The reduced-form elasticity for a positive shift in supply from region $i$ on price is:

$$
\frac{\mathrm{P}^{*}}{\gamma_{\mathrm{i}}}=\pi_{\mathrm{i}}=\frac{-\mathrm{k}_{\mathrm{xi}}}{\sum_{\mathrm{i}}^{6} \varepsilon_{\mathrm{i}} \mathrm{k}_{\mathrm{xi}}-\sum_{\mathrm{j}}^{6} \eta_{\mathrm{j}} \mathrm{k}_{\mathrm{mj}}}<0
$$

A positive shift in supply will naturally cause the price to go down. For an exporting region with a larger share of the world market, the impact of a supply shift on price is larger. For a positive demand shift, the effect is an increase in price:

$$
\frac{P^{*}}{\alpha_{j}}=\pi_{j}=\frac{k_{m j}}{\sum_{i}^{6} \varepsilon_{i} k_{x i}-\sum_{j}^{6} \eta_{j} k_{m j}}>0
$$


The larger the share of total world import, the larger the impact of a demand shift on price. The total global supply and demand shifts and impacts are computed by aggregating the exporting (importing) regions' shifts in supply (demand) weighted by each region's share of total exports (imports):

$$
\begin{aligned}
& \gamma_{t o t}=\sum_{i}^{6} k_{x i} \gamma_{i} \\
& \alpha_{t o t}=\sum_{i}^{6} k_{m i} \alpha_{i}
\end{aligned}
$$

Cumulative Sum Control Charts (Cusum) are used to detect if the cumulative price impacts are significantly different from zero (Hawkins and Olwell 1998). Let $\pi_{1}, \pi_{2}, \ldots, \pi_{9}$ represent nine annual price impacts from 2003 to 2011 for an importing or exporting region. From this, we can calculate the cumulative sums $S_{2002}, S_{2003}, \ldots, S_{2011}$. Start the cumulative sum at zero by setting $S_{2002}=0$. Calculate the other cumulative sums by adding the difference between the current average impact $\bar{\gamma}_{t}$ at time $t$ and a target value $\bar{\pi}$ :

$S_{t}=S_{t-1}+\left(\bar{\gamma}_{t}-\bar{\pi}\right)$ for $t=2003,2003, \ldots 2011$

The cumulative sums represent the differences between the computed price impacts and the target value. Here we assume that on average there are no impacts on price from supply or demand shifts, and set the target value $\bar{\pi}$ to zero. If any cumulative sum throughout the period deviates more than three standard errors from zero, we conclude that a price impact has occurred. Both negative and positive price impacts can be detected. Hence, during the period there can be both negative and positive impacts from supply or demand shifts.

\section{Empirical Results}

Using the elasticity values in Table 2, the yearly shifts in supply and demand are computed and applied to the EDM framework. The results focus on the impacts of supply and demand shifts on prices. The results are presented in Table 3:

Table 3. Average annual supply/demand shifts, reduced form elasticities, and impacts on price from 2003 to 2011 


$\begin{array}{lllll} & \text { Average } & \text { Average reduced } & \text { Average } & \text { Cumulative } \\ \text { annual S/D } & \text { form elasticities } & \text { annual price } & \text { impact }^{4} \\ \text { Region } & \text { Shift }(\bar{\gamma} \text { or } \bar{\alpha}) & \text { for price } & \text { impact } & \end{array}$

Exporters:

\begin{tabular}{lllll}
\hline Norway & $9.7 \%(2.4) * * *$ & -0.46 & $-4.5 \%(1.1)^{* * *}$ & $\mathrm{~N}$ \\
Chile & $-3.8 \%(12.3)$ & -0.2 & $0.3 \%(1.8)$ & $\mathrm{P}$ \\
Canada & $-1.8 \%(6.2)$ & -0.05 & $0.1 \%(0.3)$ & $\mathrm{NI}$ \\
UK / Ireland & $-16.5 \%(20.7)$ & -0.03 & $0.0 \%(0.7)$ & $\mathrm{P}$ \\
The Faroe & $2.8 \%(16.1)$ & -0.03 & $-0.1 \%(0.3)$ & $\mathrm{P}$ and N \\
Islands & & & & \\
ROW & $87.3 \%(109.2)$ & -0.002 & $0.0 \%(0.1)$ & $\mathrm{NI}$
\end{tabular}

Importers:

\begin{tabular}{lllll}
\hline The EU & $5.4 \%(4.1)$ & 0.38 & $2.2 \%(1.7)$ & $\mathrm{P}$ \\
mainland & & & & \\
USA & $-0.4 \%(3)$ & 0.19 & $-0.1 \%(0.6)$ & $\mathrm{N}$ \\
Japan & $-4.7 \%(7.1)$ & 0.04 & $-0.2 \%(0.3)$ & $\mathrm{N}$ \\
Russia & $21.4 . \%(8)^{* *}$ & 0.04 & $0.8 \%(0.3)^{* *}$ & $\mathrm{P}$ \\
Brazil & $13.6 \%(9.6)$ & 0.02 & $0.3 \%(0.2)$ & $\mathrm{P}$ \\
ROW & $12.8 \%(5.5)^{* *}$ & 0.1 & $1.3 \%(0.5)^{* *}$ & $\mathrm{P}$
\end{tabular}

Totals:

\begin{tabular}{lllll}
\hline Supply & $4.9 \%(2.9)$ & -0.76 & $-4.2 \%(2.4)$ & $\mathrm{N}$ \\
Demand & $5.2 \%(3.5)$ & 0.76 & $4.1 \%(2.9)$ & $\mathrm{P}$ \\
& & & & \\
Price change & - & - & $-0.5(5.1)$ & -
\end{tabular}

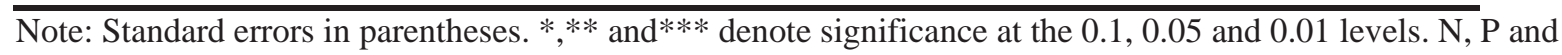
$\mathrm{NI}$ in the last column indicate Negative, Positive and No Impact on price from supply/demand shifts. Average annual shifts, price impacts and price change are geometric means. Reduced form elasticities and impacts on quantities are available from the author on request.

\footnotetext{
${ }^{4}$ Detailed results can be obtained at the author's request
} 
The structural framework is such that the actual price change and standard error of the price change are identical to the ones predicted by the model. These are reported in the last row of the table. The reduced form elasticities vary for each period because they depend on a region's share of total world imports (exports) at each point in time, and the elasticities reported in the table are averages.

The reduced form elasticities express the impact on price from a one percent positive shift in supply (demand). They are determined by the elasticities of export supply and import demand in all regions and the share of the total market for each exporting or importing region. The largest reduced form supply elasticities are those of Norway and Chile, while the EU and the U.S. have the largest demand elasticities. The aggregated total elasticities of supply and demand are -0.76 and 0.76 , and express the percentage change in price if there is a one percent increase in supply (demand) in all exporting (importing) regions.

The results show large variations in supply and demand shifts among different regions and over time. While some regions experience negative growth in supply or demand, others experience a yearly average growth at double-digit levels. The only significant average negative impact on price from supply growth is from Norway, with an average annual supply shift and impact on price of 10 and $-4.5 \%$. Large standard errors of supply shifts suggest that regional salmon supply, perhaps with the exception of Norway, is anything but smooth. The variance of the supply shifts are significantly larger in all regions compared to that of Norway (results can be obtained from the author upon request). While productivity growth in Norwegian salmon farming has been extensively studied (Asche et al. 2007, 2008; Asheim et al. 2011; Vassdal and Holst 2011; Asche and Roll 2013), a lack of data has hindered studies of other regions (Asche and Bjørndal 2011). The differences in variance of supply shifts between Norway and other regions suggest results from studies of productivity and supply growth based on Norwegian data may not be representative of other salmon-producing countries.

Even if annual average impacts are too small to have a statistically significant effect for most suppliers, the cumulative impacts from successive years with negative or positive supply shifts can be non-zero. As expected, we detect negative cumulative price impacts in Norway. We detect positive cumulative price impacts for Chile, UK/Ireland and the Faroe Islands. For the Faroe Islands there are both positive and negative cumulative price impacts. Asche and Bjørndal (2011) highlight substantial disease problems in Chile, UK/Ireland and the Faroe Islands and these are likely to be main the cause of positive price impacts. In the Faroe 
Islands, new regulations were implemented and diseases were brought under control around 2006, causing a positive cumulative price impact from supply growth in the following years. The combination of insignificant average supply shifts and price impacts, large standard errors and the detection of cumulative price impacts, indicate highly variable supply shifts and price impacts for most salmon-producing regions.

The only demand shifts where averages are significantly different from zero are those of Brazil and ROW. Although the EU's average demand shift and price impact are not significantly different from zero, demand shifts from the EU have the largest average impact on price. With the EU being the largest market for salmon, a one percent demand shift from EU has a larger impact on price than a one percent demand shift in any other region. Because of large positive shifts in demand, the impacts on price are also considerable in Russia and ROW, even if these regions consist of relatively small, although increasing shares of total salmon imports.

The cumulative price effects from shifts in demand in the EU, Russia, Brazil and ROW are all positive; demand shifts from the historically important markets US and Japan have had negative impacts on price. Thus, even if the average annual price impact is insignificant for most regions, demand shifts in all regions do indeed influence the price of salmon. The large standard errors of demand shifts and the detection of cumulative price impacts for all regions indicate that using trend variables to measure demand growth is unlikely to capture the volatility of demand shifts and their impacts on price.

While average shifts and price impacts of total supply and demand shifts are not statistically significant for most regions, the cumulative effects of successive years of supply and demand growth (or contractions) in most regions are influencing the price of salmon. On an aggregate level, the variance of total demand and supply shifts and price impacts are not significantly different. This indicates the impacts of total demand and supply shifts on price volatility are of similar degrees.

\section{Concluding Remarks}

Many food commodity prices have increased dramatically in recent years. Since changes in commodity prices are essentially due to shifts in supply relative to demand, there is a need to determine the relative effects of both supply and demand shifts to understand price fluctuations. This article presents a method for identifying regional supply and demand shifts and their impacts on price, applied to the global salmon market. The procedure allows shifts to vary independently between years. Based on an approach by Marsh (2003), yearly shifts in salmon 
supply and demand are retrieved for each exporting and importing region, and the relative impact of each supply and demand shift on price formation are determined in an EDM framework.

Both supply and demand shifts vary considerably over time and between regions. Results indicate that the average annual supply shift from Norway is the only supply shift significantly different from zero. Supply shifts from Norway are also less volatile than for all other producing regions, suggesting there are some structural differences in the production process between Norway and other producing regions. The average shifts in demand are significantly different from zero only in Russia and ROW, and high standard errors in the demand shifts for all regions suggest demand does not follow a smooth trend. With the exception of Norway, the high standard errors in regional supply and demand shifts imply that predicting future supply, demand, and price changes based on previous price and quantity data should be approached with extreme caution. While average annual supply and demand shifts are insignificant in most regions, we detect cumulative price impacts for all but one region (Canada). This indicates that the year-to-year variation in demand and supply shifts is so large that one must expect annual supply and demand shifts in almost every exporting and importing region to impact salmon prices.

The application to the salmon market provides a foundation for further research on identifying variables and events that influence supply and demand, and the results may serve as a useful baseline for assessing the impacts of potential future supply and demand shifts in the salmon market. For any market with unstable price behaviour, the procedure presented in this article could prove a useful instrument for determining the relative impact of supply and demand shifts on price.

\section{Acknowledgements}

I thank Paul Aandahl, his colleagues at the Norwegian Seafood Council, and Sigbjørn Tveterås for providing data and background material. Øystein Myrland, Henry Kinnucan, and two anonymous reviewers provided helpful comments and suggestions. I gratefully acknowledge these contributions to this work 


\section{References}

Alston, J.M., Beddow, J.M. and Pardey, P.G. (2009) Agricultural research, productivity, and food prices in the long run. Science 325, 4-5.

Andersen, T.B., Roll, K.H. and Tveterås, S. (2008) The price responsiveness of salmon supply in the short and long run. Marine Resource Economics 23, 425-437.

Asche, F. (1996) A system approach to the demand for salmon in the European Union. Applied Economics 28, 97-101.

Asche, F. (2008) Farming the sea. Marine Resource Economics 23, 527-547.

Asche, F. and Bjørndal, T. (2011) The Economics of Salmon Aquaculture, 2nd edn. WileyBlackwell, London.

Asche, F., Bjørndal, T. and Salvanes, K.G. (1998) The demand for salmon in the European Union: the importance of product form and origin. Canadian Journal of Agricultural Economics 46, 69-81.

Asche, F., Bremnes, H., Salvanes, K.G. and Wessells, C.R. (1999) Product aggregation, market integration, and relationships between prices: an application to world salmon markets. American Journal of Agricultural Economics 81, 568-581.

Asche, F., Dahl, R.E., Gordon, D. V., Trollvik, T. and Aandahl, P. (2011) Demand Growth for Atlantic Salmon: The EU and French Markets. Marine Resource Economics 26, 255265.

Asche, F., Guttormsen, A.G. and Nielsen, R. (2013) Future challenges for the maturing Norwegian salmon aquaculture industry: An analysis of total factor productivity change from 1996 to 2008. Aquaculture 396-399, 43-50.

Asche, F., Guttormsen, A.G., Sebulonsen, T. and Sissener, E.H. (2005) Competition between farmed and wild salmon: the Japanese salmon market. Agricultural Economics 33, $333-$ 340.

Asche, F. and Roll, K.H. (2013) Determinants of Inefficiency in Norwegian Salmon Aquaculture. Aquaculture Economics \& Management 17, 300-321.

Asche, F., Roll, K.H. and Tveterås, R. (2007) Productivity growth in the supply chainanother source of competitiveness for aquaculture. Marine Resource Economics 22, 329_ 334.

Asche, F., Roll, K.H. and Tveterås, S. (2008) Future Trends in Aquaculture : Productivity Growth and Increased Production. In: Aquaculture in the Ecosystem. (eds M. Holmer, K. Black, C.M. Duarte, N. Marbà and I. Karakassis). Springer, New York, pp 271-292.

Asche, F., Salvanes, K.G. and Steen, F. (1997) Market delineation and demand structure. American Journal of Agricultural Economics 79, 139-150. 
Asheim, L.J., Dahl, R.E., Kumbhakar, S.C., Øglend, A. and Tveterås, R. (2011) Are Prices or Biology Driving the Short-Term Supply of Farmed Salmon? Marine Resource Economics 26, 343-357.

Balagtas, J. V. and Holt, M.T. (2009) The Commodity Terms of Trade, Unit Roots, and Nonlinear Alternatives: A Smooth Transition Approach. American Journal of Agricultural Economics 91, 87-105.

Bjørndal, T., Salvanes, K.G. and Andreassen, J. (1992) The demand for salmon in France: the effects of marketing and structural change. Applied Economics 24, 1027-1034.

Chidmi, B., Hanson, T. and Nguyen, G. (2012) Substitutions between Fish and Seafood Products at the US National Retail Level. Marine Resource Economics 27, 359-370.

Coelli, T.J., Rao, D.S.P., O’Donnell, C. and Battese, G.E. (2005) An introduction to efficiency and productivity analysis. Springer, Boston.

Davis, C., Lin, B.-H. and Yen, S. (2007) Consumer demand for meat cuts and seafood. In: American Agricultural Economics Association. 2007 Annual Meeting, 29 July-1 August, Portland, OR. Paper presented at the 2007 Annual Meeting of the American Agricultural Economics Association, July 29-August 1, Portland , OR. .

Deaton, A. and Muellbauer, J. (1980) Economics and consumer behaviour. Cambridge University Press, Cambridge, MA.

DeVoretz, D. and Salvanes, K.G. (1993) Market structure for farmed salmon. American Journal of Agricultural Economics 75, 227-233.

Enders, W. and Holt, M.T. (2012) Sharp Breaks or Smooth Shifts? an Investigation of the Evolution of Primary Commodity Prices. American Journal of Agricultural Economics 94, 659-673.

FAO (2014) The State of World Fisheries and Aquaculture 2014. 223 pp. FAO Fisheries and Aquaculture Department, Rome.

Fousekis, P. and Revell, B. (2004) Retail fish demand in great britain and its fisheries management implications. Marine Resource Economics 19, 495-510.

Gilbert, C.L. (2010) How to Understand High Food Prices. Journal of Agricultural Economics 61, 398-425.

Harvey, D. and Kellard, N.M. (2010) The Prebisch-Singer hypothesis: four centuries of evidence. The Review of Economics and Statistics 92, 367-377.

Hawkins, D. and Olwell, D. (1998) Cumulative Sum Charts and Charting for Quality Improvement. Springer, New York.

Hong, T.T.K. and Duc, N.M. (2009) Competition Between Us Catfish And Imported Fish: A Demand System Analysis. Journal of Agricultural Science and Technology 2009, 111118. 
Houck, J.P. (1986) Elements of agricultural trade policies. Macmillan, New York.

Jones, K., Wozniak, S. and Walters, L. (2013) Did the Proposed Country-of-Origin Law Affect Product Choices? The Case of Salmon. Journal of Food Products and Marketing 19, 62-76.

Kinnucan, H.W. and Myrland, Ø. (2005) Effects of income growth and tariffs on the world salmon market. Applied economics 37, 1967-1978.

Kinnucan, H.W. and Myrland, Ø. (2006) Welfare effects of supply expansion with trade restrictions: The case of salmon. Journal of International Agricultural Trade and Development 2, 185-204.

Kinnucan, H.W., Xiao, H., Hsia, C.-J. and Jackson, J.D. (1997) Effects of health information and generic advertising on US meat demand. American Journal of Agricultural Economics 79, 13-23.

Knapp, G., Roheim, C.A. and Anderson, J. (2007) The great salmon run: competition between wild and farmed salmon. Washington, D.C.

Kumbhakar, S.C. and Lovell, C.A.K. (2000) Stochastic Frontier Analysis. Cambridge University Press, Cambridge.

Leontief, W. (1929) Ein Versuch zur statistischen Analyse von Angebot und Nachfrage. Weltwirtschaftliches Archiv, 1-53.

Marsh, J.M. (2003) Impacts of Declining US Retail Beef Demand on Farm-Level Beef Prices and Production. American Journal of Agricultural Economics 85, 902-913.

Muhammad, A. and Jones, K.G. (2011) Source-Based Preferences and U.S. Salmon Imports. Marine Resource Economics 26, 191-209.

Muth, R.F. (1964) The derived demand curve for a productive factor and the industry supply curve. Oxford Economic Papers 16, 221-234.

Piggott, R.R. (1992) Some old truths revisited. Australian Journal of Agricultural Economics 36, $117-40$.

Pingali, P. (2007) Westernization of Asian diets and the transformation of food systems: implications for research and policy. Food policy 32, 281-298.

Sakai, Y., Yagi, N., Ariji, M., Takahara, A. and Kurokura, H. (2009) Substitute and complement relations among various fish species in the Japanese market: implications for fishery resource management. Fisheries Science 75, 1079-1087.

Serra, T. and Zilberman, D. (2013) Biofuel-related price transmission literature: A review. Energy Economics 37, 141-151. 
Singh, K., Dey, M.M. and Surathkal, P. (2012) Analysis of a Demand System for Unbreaded Frozen Seafood in the United States Using Store-level Scanner Data. Marine Resource Economics 27, 371-387.

Sun, C. and Kinnucan, H.W. (2001) Economic impact of environmental regulations on southern softwood stumpage markets: A reappraisal. Southern Journal of Applied Forestry 25, 108-115.

Tiffin, R. and Arnoult, M. (2010) The demand for a healthy diet: estimating the almost ideal demand system with infrequency of purchase. European Review of Agricultural Economics 37, 501-521.

Tomek, W.G. (2000) Commodity prices revisited. Agricultural and Resource Economics Review 29/2, 125-137.

Torrissen, O., Olsen, R.E., Toresen, R., et al. (2011) Atlantic Salmon ( Salmo salar ): The "Super-Chicken" of the Sea? Reviews in Fisheries Science 19, 257-278.

Trostle, R. (2008) Global Agricultural Supply and Demand: Factors Contributing to the Recent Increase in Food Commodity Prices, WRS-0801 edn. USDA Economic Research Service, US Department of Agriculture, Washington, D.C.

Tveterås, S., Asche, F. and Bellemare, M. (2012) Fish is food-the FAO's fish price index. PLoS One 7, 1-10.

Vassdal, T. and Holst, H.M.S. (2011) Technical Progress and Regress in Norwegian Salmon Farming: A Malmquist Index Approach. Marine Resource Economics 26, 329-341.

Xie, J., Kinnucan, H.W. and Myrland, Ø. (2009) Demand elasticities for farmed salmon in world trade. European Review of Agricultural Economics 36, 425-445.

Xie, J. and Myrland, Ø. (2011) Consistent Aggregation in Fish Demand: A Study of French Salmon Demand. Marine Resource Economics 26, 267-280.

Øglend, A. (2013) Recent Trends in Salmon Price Volatility. Aquaculture Economics \& Management 17, 281-299. 


\section{Appendix}

Computation of demand and supply shifts

Shifts in demand and supply between two periods are illustrated for a market with one exporter and one importer in figure 3.

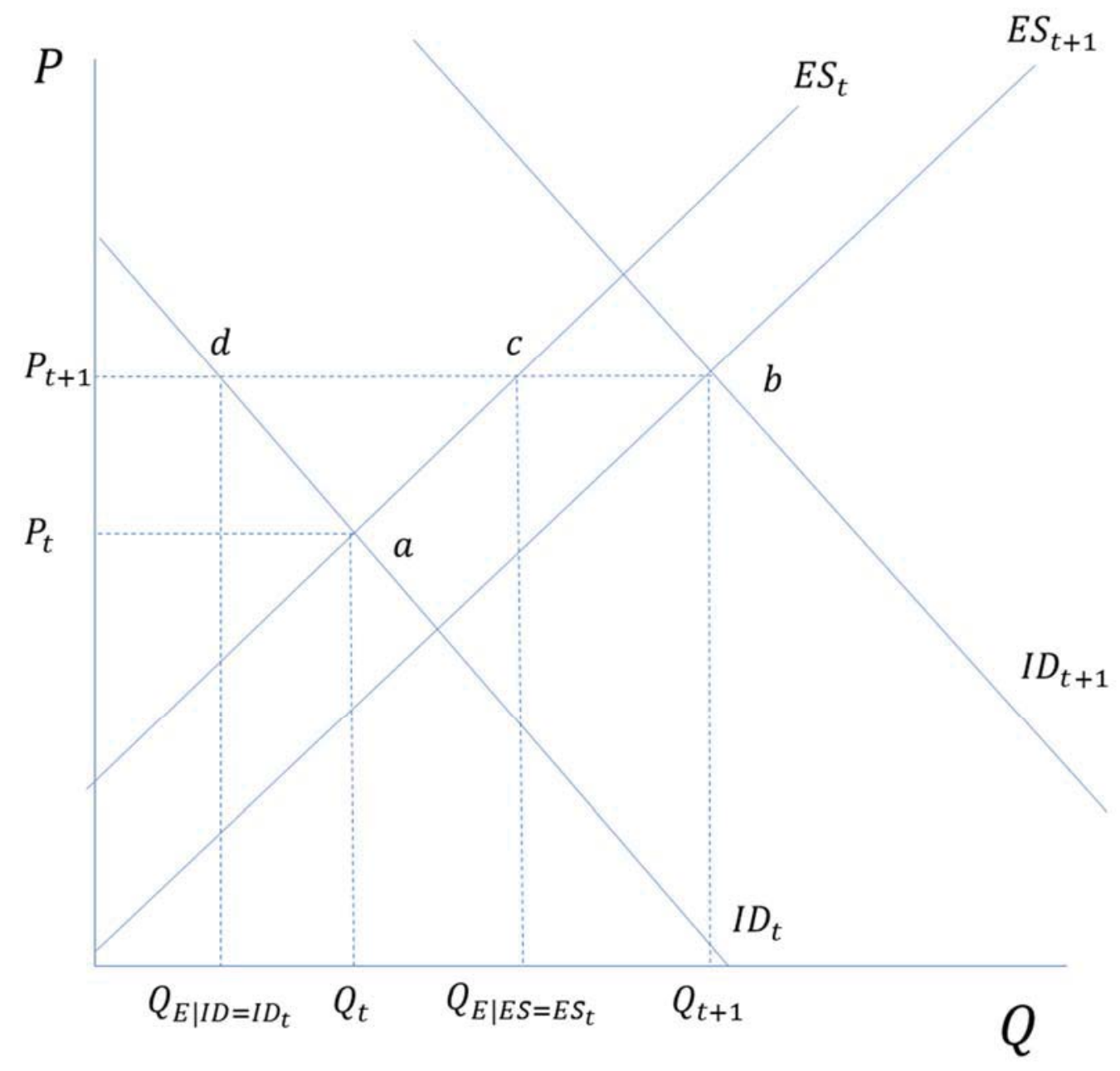

Figure 3. The horizontal shifts in import demand (ID) and export supply (ES) for a market with one exporter and one importer.

Let $Q_{t}$ and $P_{t}$ represent the observed quantity and price levels in period $t$, and $Q_{t+1}$ and $P_{t+1}$ be the observed quantity and price levels in period $t+1$. The supply and demand schedules for each period are illustrated by the curves $E S$ and $I D$. The shifts in supply and demand cause price and quantity to move from point a to point $b$ in figure 3. Given the supply schedule from period $t, Q_{E \mid E S=E S_{t}}$ is the expected quantity level at the observed price in period $t+1$.

$Q_{E \mid E S=E S_{t}}$ is thus the quantity level that would occur if only demand had shifted and supply had remained unchanged. The absolute shift in supply is defined as the horizontal difference 
between the supply schedules in period $t$ and $t+1$. This is equal to the distance between points $c$ and $b$ in the figure, or equivalently, between $Q_{E \mid E S=E S_{t}}$ and $Q_{t+1}$. For a demand shift, $Q_{E \mid I D=I D_{t}}$ is analogous to $Q_{E \mid E S=E S_{t}}$. The absolute demand shift is similarly defined as the horizontal difference between the demand schedules in period $t$ and $t+1$. This is measured by the distance between points $d$ and $b$, or between $Q_{E \mid I D=I D_{t}}$ and $Q_{t+1}$. It is preferable to measure these shift in relative terms. Previous measures of supply and demand shifts have specified these shifts relative to the expected quantity $Q_{E \mid E S=E S_{t}}$ or $Q_{E \mid I D=I D_{t}}$ (Asche et al. 1998; Marsh 2003; Kinnucan and Myrland 2006). Seeing that the change in question here is the change between two periods, the relative change in demand or supply is here specified as the change relative to the quantity level of the first period $Q_{t}$. This allows for a simple interpretation of the shifts, where they can be defined as the percentage change in quantity demanded (supplied) at a given price. Kinnucan and Myrland (2006) derived a one-step procedure for estimating the relative shift in supply between two periods, of which this adjustment is imposed. As illustrated in the figure, the relative shift in supply from period $t$ to $t+1$ can be defined as follows:

$$
\gamma=\left(Q_{t+1}-Q_{E \mid E S=E S_{t}}\right) / Q_{t}
$$

Adding and subtracting $Q_{t}$ in the numerator on the right side of (A1) yields:

$$
\left.\gamma=\left(Q_{t+1}-Q_{t}\right) / Q_{t}-\left(Q_{E \mid E S=E S_{t}}-Q_{t}\right)\right) / Q_{t}=Q^{*}-Q_{E}^{*}
$$

where $\left(Q_{t+1}-Q_{t}\right) / Q_{t}=Q^{*}$ is the percentage quantity change from period $t$ to period $t+1$. $\left.\left(Q_{E \mid E S=E S_{t}}-Q_{t}\right)\right) / Q_{t}=Q_{E}^{*}$ is the relative difference between the expected quantity in period $t+1$ and the observed quantity in period t. In other words, it is the expected percentage change in quantity under the assumption of no shift in supply. As can be observed in the figure, the price change corresponding to $Q_{E}^{*}$ is $\frac{P_{t+1}-P_{t}}{P_{t}}=P^{*}$. This allows for the common definition of price elasticity of supply to be used:

$$
\varepsilon=\frac{\% \Delta Q}{\% \Delta P}
$$


Inserting for the expected quantity change $Q_{E}^{*}$, a predetermined elasticity value and the observed price change yields the following:

$$
Q_{E}^{*}=\varepsilon P^{*}
$$

Inserting for $Q_{E}^{*}$ from (A2) into (A1'), a supply shift between two periods can now be defined as:

$$
\gamma=Q^{*}-\varepsilon P^{*}
$$

(A1'') is simply the percentage change in quantity, minus the percentage price change multiplied by the elasticity of supply. The analogous shift in demand is obtained by following the same procedure, replacing the supply elasticity with the demand elasticity. This yields the following expression for the demand shift:

$$
\alpha=Q^{*}-\eta P^{*}
$$

Equations (A1") and (A3) are identical to equations (1) and (2). These shifts are horizontal shifts in supply and demand, i.e. measured in the quantity direction. The shifts can be measured in the price or quantity direction, i.e. vertically or horizontally. The associated vertical shifts are obtained by dividing the horizontal shift by minus the corresponding elasticity (Sun and Kinnucan, 2001). The equivalent supply and demand shifts measured in the price direction are as follows:

$$
\begin{aligned}
& \frac{\gamma}{-\varepsilon}=-\frac{Q^{*}}{\varepsilon}+P^{*} \\
& \frac{\alpha}{-\eta}=-\frac{Q^{*}}{\eta}+P^{*}
\end{aligned}
$$


where the vertical supply shift indicates the percentage change in the price that exporters require to sell a given quantity. A demand shift in the price direction indicates the percentage change in the price that importers are willing to pay for a given quantity of salmon. A positive vertical demand shift indicates a higher willingness to pay for a given quantity, while a positive vertical supply shift indicates that exporters contract their supply, i.e. that they demand a higher price for a given quantity. Both quantity and price are treated as endogenous at the market level, and whether one measures the shift in the price or quantity direction is a matter of preferences. In this article the horizontal shifts in demand and supply are computed. 